\title{
Preferential targeting of MCL-1 by a hydrocarbon-stapled BIM BH3 peptide
}

\author{
Abbas Hadji ${ }^{1}$, Greta K. Schmitt ${ }^{1}$, Mathew R. Schnorenberg ${ }^{1,2}$, Lauren Roach ${ }^{1}$, \\ Connie M. Hickey ${ }^{1}$, Logan B. Leak ${ }^{1}$, Matthew V. Tirrell ${ }^{2}$ and James L. LaBelle ${ }^{1}$ \\ ${ }^{1}$ Department of Pediatrics, Section of Hematology/Oncology/Stem Cell Transplantation and Committee on Cancer Biology, \\ University of Chicago, Chicago, IL 60637, USA \\ ${ }^{2}$ Pritzker School of Molecular Engineering, University of Chicago, Chicago, IL 60637, USA \\ Correspondence to: James L. LaBelle, email: jlabelle@peds.bsd.uchicago.edu
}

Keywords: MCL-1; BIM; BH3 mimetic; stapled peptides; apoptosis

Received: February 08, $2019 \quad$ Accepted: October 04, $2019 \quad$ Published: October 22, 2019

Copyright: Hadji et al. This is an open-access article distributed under the terms of the Creative Commons Attribution License 3.0 (CC BY 3.0), which permits unrestricted use, distribution, and reproduction in any medium, provided the original author and source are credited.

\section{ABSTRACT}

BCL-2 family proteins are central regulators of apoptosis and represent prime therapeutic targets for overcoming cell death resistance in malignancies. However, plasticity of anti-apoptotic members, such as MCL-1, often allows for a switch in cell death dependency patterns that lie outside the binding profile of targeted BH3-mimetics. Therefore discovery of therapeutics that effectively inactivate all anti-apoptotic members is a high priority. To address this we tested the potency of a hydrocarbon stapled BIM BH3 peptide (BIM SAHB ${ }_{A}$ ) to overcome both BCL-2 and MCL-1 apoptotic resistance given BIM's naturally wide ranging affinity for all BCL-2 family multidomain members. BIM SAHB ${ }_{A}$ effectively killed diffuse large B-cell lymphoma ( $D L B C L)$ cell lines regardless of their anti-apoptotic dependence. Despite BIM BH3's ability to bind all BCL-2 anti-apoptotic proteins, BIM SAHB ${ }_{A}$ 's dominant intracellular target was MCL-1 and this specificity was exploited in sequenced combination $\mathrm{BH} 3-$ mimetic treatments targeting $\mathrm{BCL}-2, \mathrm{BCL}-\mathrm{X}_{\mathrm{L}}$, and $\mathrm{BCL}-\mathrm{W}$. Extending this MCL-1 functional dependence, mouse embryonic fibroblasts (MEFs) deficient in MCL-1 were resistant to mitochondrial changes induced by BIM SAHB ${ }_{A^{*}}$. This study demonstrates the importance of understanding BH3 mimetic functional intracellular affinities for optimized use and highlights the diagnostic and therapeutic promise of a BIM BH3 peptide mimetic as a potential MCL-1 inhibitor.

\section{INTRODUCTION}

The BCL-2 family can be divided into multidomain anti-apoptotic (e.g. BCL-2, BCL-X, BCL-W, MCL-1, BFL-1) and pro-apoptotic (e.g. BAK, BAX) proteins. The functional interactions between these anti- and pro-apoptotic partners is controlled by a third group of proteins known as $\mathrm{BH} 3$-only proteins (e.g. BIM, BID, PUMA, BIK, BAD, NOXA, BMF) which contain one of four conserved BCL-2 homology (BH) domains. BH3-only proteins can directly bind and activate BAX/BAK or can insert their amphipathic BH3 $\alpha$-helix into a groove on anti-apoptotic protein target(s) resulting in release and subsequent indirect BAX/BAK activation [1]. Cancer cells have long been known to evade cell death through overexpression of anti-apoptotic BCL-2 members or through down-regulation of BH3-only proteins [1]. To overcome these hurdles there is a great pharmacologic crusade to develop agents that directly engage BCL-2 family proteins to induce death regardless of the cell's origin or genetic perturbations [2]. Despite early promise, many BH3-mimetics, have not effectively translated to the clinic or have been proven to work, at least in part, independent of the BCL-2 network [3-5].

Functional redundancy within the BCL-2 family can make it challenging to tailor effective therapeutic strategies without incurring resistance through upregulation of BCL-2 proteins that lie outside the mimetic's binding profile [3, 6-9]. This is exemplified by diffuse large B-cell lymphoma (DLBCL) where MCL-1 contributes to intrinsic and acquired resistance to the rationally designed polyselective BCL-2, BCL- $\mathrm{X}_{\mathrm{L}}$, and BCL-W inhibitor 
ABT-737 and the monoselective BCL-2 inhibitor ABT-199 [10, 11]. Despite the predominance of BCL-2 protein expression in DLBCL, either through the $\mathrm{t}(14 ; 18)$ translocation and/or elevated $B C L 2$ copy numbers, many BCL-2 ${ }^{\text {High }}$ DLBCL are resistant to direct BCL-2 inhibition and ultimately rely on MCL-1 for survival [11]. Additionally, although activated B-cell-like (ABC) DLBCL may rely on MCL-1 to a greater extent than germinal center B-cell-like (GCB) DLBCL, protein expression alone fails to predict reliance on BCL-2 or MCL-1 in either subtype. Rather, functional sequestration of pro-apoptotic BAK and BIM appear to define sensitivity to $\mathrm{BH} 3$-mimetic treatment $[10$, 12]. The importance of releasing BIM for cell death activation is exemplified by the treatment of BCL- $2^{\text {High }}$ DLBCL with ABT-199 or the BCL-X $\mathrm{L}_{\mathrm{L}}$-selective inhibitor A-1155463 which results in ejection of BIM from these proteins but subsequent sequestration by MCL-1 [11]. The significance of this paradigm is reflected in encouraging results using BCL-2/BCL- $\mathrm{X}_{\mathrm{L}}$ targeting BH3-mimetics in combination with agents that down-regulate MCL-1 in murine models of $M Y C-B C L 2$ double-hit lymphoma and human DLBCL [13, 14]. It is clear that release of endogenous BIM sequestered by multiple anti-apoptotics is key to overcoming cell death resistance in diseases such as DLBCL.

The physiologic dominance of BIM in regulating apoptosis in hematopoietic cells is reflected in the ability of its $\mathrm{BH} 3$ death domain to tightly engage the BH3-binding groove of all anti-apoptotic proteins and directly activate BAX and BAK [15]. To exploit BIM's natural death-inducing functions we and others have shown that a hydrocarbon-stapled peptide modeled after the BIM $\mathrm{BH} 3 \alpha$-helix (BIM SAHB ${ }_{A}$ ) broadly targets BCL-2 proteins with high affinity ex vivo, blocks inhibitory anti-apoptotic interactions, directly triggers BAX activation, dissociates BAK from MCL-1, and induces dose-responsive and BH3 sequence-specific cell death in hematologic cancers [16-18]. In the present study, we investigated the effect of $\mathrm{BIM} \mathrm{SAHB}_{A}$ on human DLBCL that differentially express and functionally depend on various BCL-2 anti-apoptotic proteins for survival [10]. We found that BIM $\mathrm{SAHB}_{A}$ induced apoptosis in DLBCL regardless of anti-apoptotic protein expression but that it did so most effectively in DLBCL that were increasingly resistant to ABT-737 and ABT-199. These results led to the finding that BIM $\mathrm{SAHB}_{A}$ preferentially displaced endogenous BIM from MCL-1 in these cells. Treatment with BIM $\mathrm{SAHB}_{A}$ sensitized DLBCL to ABT-737 by preventing BIM relocation onto MCL-1 following displacement from BCL-2. BIM SAHB 's functional affinity for MCL-1 and induction of apoptosis at the level of the mitochondria was confirmed in MCL-1 deficient mouse embryonic fibroblasts (MEFs). This work highlights the importance of displacement and sequestration of BIM by anti-apoptotic BCL-2 proteins and further implicates a functional role of MCL-1 in apoptotic resistance in DLBCL. This study also illuminates the use of peptide-based $\mathrm{BH} 3$ mimetics to uncover biologically relevant cell death mechanisms and confirms that functional intracellular BH3-mimetic affinities for anti-apoptotic proteins may only partially reflect their acellular binding profiles.

\section{RESULTS}

\section{Inverse correlation between DLBCL sensitivity to BIM SAHB ${ }_{A}$ and ABT-737/ABT-199}

A panel of 18 human DLBCL cell lines was treated with increasing concentrations of BIM SAHB , ABT-737, and ABT-199 to determine cell death as a result of distinctive anti-apoptotic targeting (Figure 1 and Supplementary Figure 1A). The cell lines were divided into 3 groups based on their ABT-737 sensitivity: ABT-737 sensitive, ABT-737 moderately sensitive, and ABT-737 resistant (Figure 1A). Our ABT-737 sensitivity profiles were similar to those previously reported using other measures of cell death, namely Annexin V positivity and ATP content $[10,11]$. BCL-2 dependence in these cell lines was reflected in similar results following treatment with ABT-199 (Supplementary Figure 1A). Together, these results support increased BCL- $\mathrm{X}_{\mathrm{L}}$ dependence in OCI-Ly10 and increased MCL-1 dependence in SU-DHL-10, HT, Pfeiffer, SU-DHL-5, SU-DHL-8, OCI-Ly7, and OCI-Ly4 cell lines as previously reported $[10,11,17]$. In contrast to treatment with ABT-737 and ABT-199, BIM $\mathrm{SAHB}_{A}$ induced dose-responsive cell death in all DLBCL cell lines with $\mathrm{EC}_{50}$ 's ranging from $2 \mu \mathrm{M}$ to $18 \mu \mathrm{M}$ (Figure 1B and Supplementary Table 1). Like treatment with ABT-737 and ABT-199, DLBCL could be divided into two groups based on their sensitivities to $\mathrm{BIM} \mathrm{SAHB}_{A}$ : BIM SAHB ' sensitive' and BIM SAHB 'moderately sensitive' (Figure 1B). No death was measured in any cell line treated with a hydrocarbon-stapled BH3

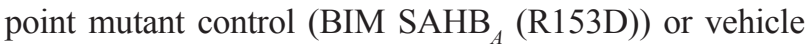
alone indicating BIM-BH3 sequence-specific cell death induction (Supplementary Figure 1B and 1C) [16, 17, 19]. Based on our treatment analyses, there appeared to be an inverse correlation between DLBCL responses to ABT-737/

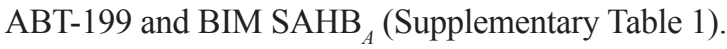

\section{BIM SAHB ${ }_{A}$ induces caspase activation in DLBCL regardless of BCL-2 family protein expression}

To confirm that BIM $\mathrm{SAHB}_{A}$ treatment lead to the activation of the intrinsic apoptotic pathway and MOMP, activated caspase 3/7 was measured six hours following treatment of DLBCL with BIM $\mathrm{SAHB}_{A}$ at their individual $\mathrm{EC}_{50}$ (Figure 2A). Cell death correlated with caspase $3 / 7$ activation in all cell lines. The relative differences in caspase 3/7 activation between DLBCL may reflect differences in the kinetics of cell death in individual cell lines. Regardless, DLBCL partially or fully 
resistant to ABT-737 (shown in blue and red) had similar fold caspase activation compared to ABT-737 sensitive DLBCL (shown in green) (Figure 2A). Representative cell death morphology following treatment with BIM $\mathrm{SAHB}_{A}$ displayed classical hallmarks of apoptosis such as cellular membrane blebbing, cell shrinkage, chromatin marginalization, and nuclear fragmentation consistent with previous findings (Figure 2B) [17]. No correlation existed between $\mathrm{BIM} \mathrm{SAHB}_{A}$-induced killing and protein expression levels of BCL-2, BCL-X ${ }_{L}$, or MCL-1 (Figure $2 \mathrm{C}$ and Supplementary Figure $2 \mathrm{~A}-2 \mathrm{C}$ ). This is similar to other reports where no correlations were measured between protein expression of BCL-2 and BCL- $\mathrm{X}_{\mathrm{L}}$ and DLBCL responses to ABT-737 or ABT-199 [10, 11]. There was also no correlation in apoptosis and levels of other BCL-2 proteins known to be associated with cell death resistance in B-cell lymphomas including BIM, BID, PUMA, BAX, or BAK (Supplementary Figure 2D-2H) $[10,12,20-23]$. Given the importance of release of BIM for apoptosis induction in DLBCL, these results suggested that BIM $\mathrm{SAHB}_{A}$ was able to block endogenous BIM binding to $\mathrm{MCL}-1, \mathrm{BCL}-2$ and/or $\mathrm{BCL}_{-} \mathrm{X}_{\mathrm{L}}$ expressing cells regardless of their sensitivity to ABT-737/ABT-199.

\section{BIM SAHB ${ }_{A}$ dissociates BIM from MCL-1 to a greater extent than BCL-2}

We next sought to investigate the ability of BIM $\mathrm{SAHB}_{A}$ to release endogenous BIM from BCL-2 or MCL-1 in DLBCL that were sensitive (OCI-Ly1 > SU-DHL-6 > OCI-Ly8) or resistant (SU-DHL-5) to ABT737 (Figure 1A, Supplementary Table 1) $[10,11]$. The three ABT-737 sensitive cell lines were chosen as they represent an array of DLBCL phenotypes based on predominant antiapoptotic BCL-2 family member expression (e.g. BCL-2,

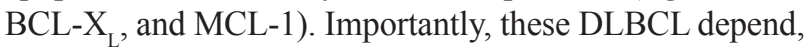
even if partially, on BCL-2, rather than BCL- $\mathrm{X}_{\mathrm{L}}$ for cell death control $[10,13]$. Treatment of individual cell lines with the $\mathrm{EC}_{50}$ of either ABT-737 or BIM SAHB $A$ alone was followed by immunoprecipitation of BCL-2 and MCL-1
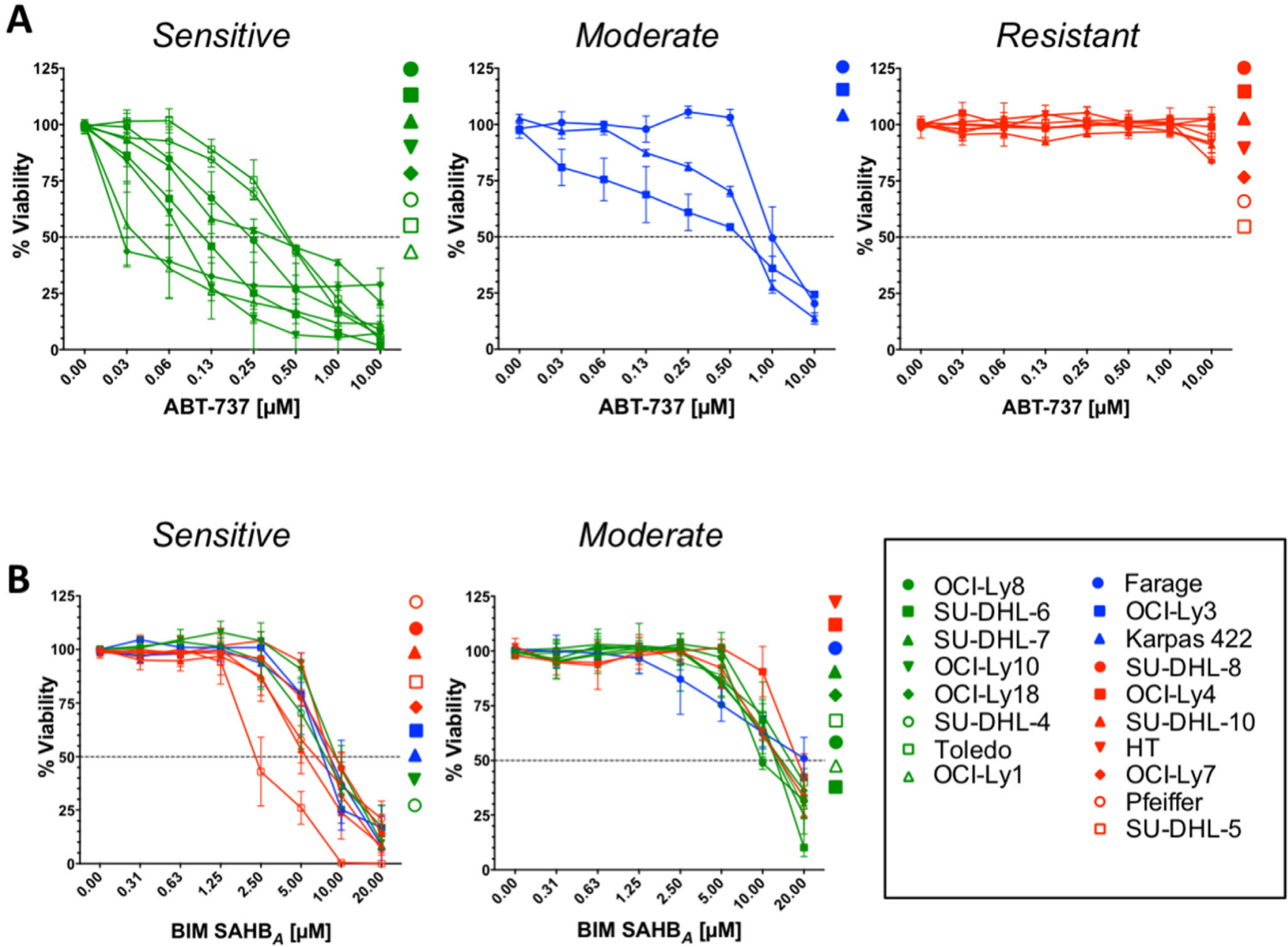

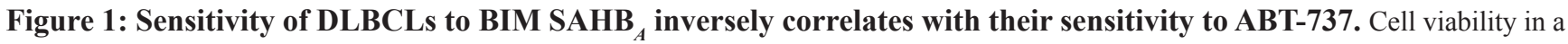
panel of human DLBCL cell lines was measured after 24-hr incubation with increasing concentrations of (A) ABT-737 or (B) BIM SAHB . Percent (\%) viability was calculated as a percentage of control (DMSO) treated cells. Dose-response curves indicating highest sensitivity to ABT-737 are in green, those indicating moderate sensitivity to ABT-737 are in blue, and those indicating low to no sensitivity to ABT-737 are in red. Error bars are mean $\pm \mathrm{SEM}$ for at least three independent preparations of cell and $\mathrm{BH} 3$ mimetic treatments. 


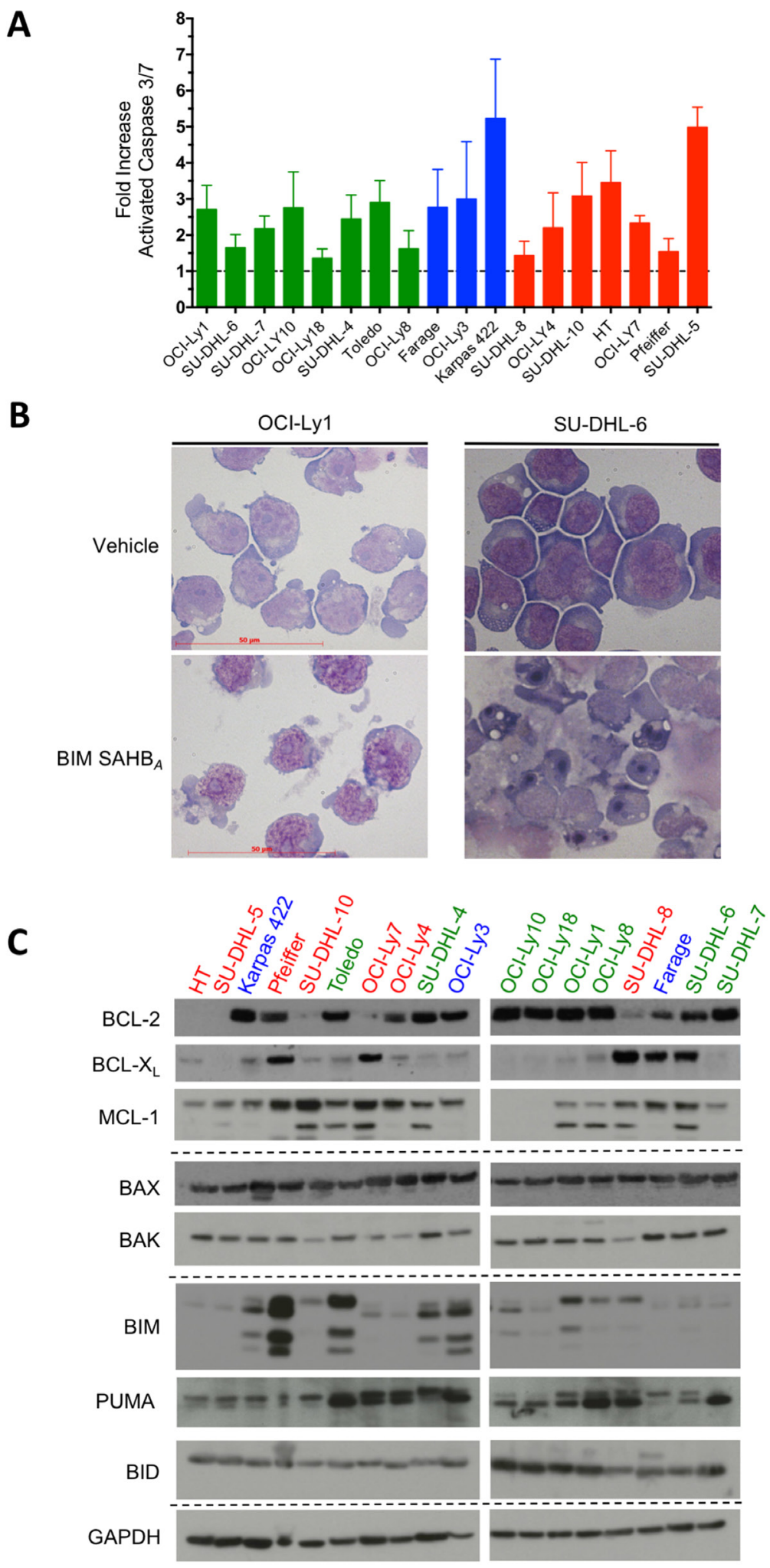

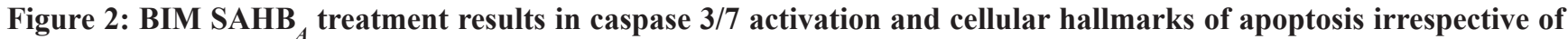
BCL-2 family protein expression in DLBCL. (A) DLBCL cell lines were treated $\mathrm{BIM} \mathrm{SAHB}_{A}$ at their respective $\mathrm{EC}_{50}$ for 6-hr and activation of the intrinsic apoptotic pathway was assessed by monitoring the cleavage of pro-luminescent caspase 3/7 substrate. Caspase

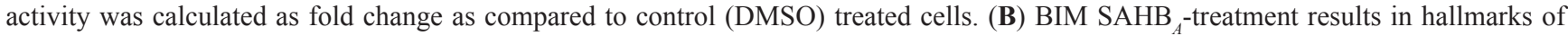
apoptosis such as cellular membrane blebbing, cell shrinkage, chromatin marginalization, and nuclear fragmentation. (C) Western blot analysis of BCL-2 proteins in DLBCL cell lines. Colors of each cell line reflect their ABT-737 sensitivity patterns as depicted in Figure 1 and Supplementary Figure 1. Error bars are mean \pm SEM for at least three independent preparations of cell and BIM SAHB ${ }_{A}$ treatments. 
and immunoblotting for endogenous BIM. As expected, treatment with ABT-737 resulted in dissociation of BIM from BCL-2 in BCL-2- expressing DLBCL (Figure 3). Once dissociated, BIM became sequestered by MCL-1, as measured particularly in OCI-Ly8 and SU-DHL-6 cells where the MCL-1:BIM complex following treatment with ABT-737 was greater than control treated cells (Figure $3 \mathrm{~A}$ and $3 \mathrm{C}$ ). In contrast, treatment with BIM SAHB $\mathrm{S}_{A}$ led to measurable, but minimal, displacement of endogenous BIM from BCL-2 in comparison to ABT-737. BIM SAHB treatment resulted in much greater dissociation of BIM from MCL-1 with no detectable increased accumulation on BCL-2 in all three cell lines (Figure 3). Thus, although BIM $\mathrm{SAHB}_{A}$ was better able to dissociate endogenous BIM from MCL-1, it was still able to prevent redistribution of BIM to BCL-2 [17]. Given these results, we were interested if stepwise treatment with ABT-737 and BIM SAHB Sesulted $_{A}$ in improved dissociation of BIM from either BCL-2 or MCL-1 and blockage of subsequent binding of released BIM on the alternate anti-apoptotic protein. To test this, cells were treated with either ABT-737 or BIM $\mathrm{SAHB}_{A}$ for three hours followed by addition of the other compound (i.e. ABT-737 + $\mathrm{BIM} \mathrm{SAHB}_{A}$ or $\mathrm{BIM} \mathrm{SAHB}_{A}+$ ABT-737). BIM SAHB ${ }_{A}$ was unable to release relocated BIM from MCL-1 that was dissociated from BCL-2 upon treatment first with ABT-737 (Figure 3). The increased BIM:MCL-1 association following treatment with ABT-737 overwhelmed the ability of BIM SAHB So effectively target MCL-1 at the same doses used during monotherapy. However, treatment with $\mathrm{BIM} \mathrm{SAHB}_{A}$ before ABT-737 led to relocation of BIM from both BCL-2 and
MCL-1. This phenomenon was greatest in OCI-Ly8 and SU-DHL-6 (Figure 3A and 3C) [10, 13]. In fact, although monotherapy of SU-DHL-5 and OCI-Ly1 with BIM $\mathrm{SAHB}_{A}$ led to release of endogenous BIM from MCL-1, this effect was largely lost in both combination treatments (Figure 3B and Supplementary Figure 3A) [24, 25]. There were no gross differences in expression of BCL-2, MCL-1, or BIM during the six hour treatment timeframe in any cell line following individual or combination treatments (Supplementary Figure 4). Dissociation of BAK from MCL-1 and activation of BAX in these cell lines may also have played a role in cell death following BIM SAHB ${ }_{A}$ treatment as has been reported previously [17, 26]. Dissociation of BAX from BCL-2 also occurs in these cell lines following treatment with both ABT-737 and BIM $\mathrm{SAHB}_{A}$ (Supplementary Figure 5).

\section{BIM SAHB $_{A}$ sensitizes DLBCL to ABT-737}

To test if sequential treatment would lead to differential effects on cell viability, DLBCL were treated as above and cell death was measured after 24 hours. Consistent with the BIM relocation results (Figure 3 and Supplementary Figure 3A) treatment with BIM SAHB prior to ABT-737 led to increased cell death when compared to the opposite treatment or monotherapy with either compound (Figure 4 and Supplementary Figure 3B). Equivalent results were measured when cells were treated with ABT-737 alone or with ABT-737 followed by BIM $\mathrm{SAHB}_{A}$ as was predicted by our BIM relocation data. The largest effect was measured in OCI-Ly8 correlating with
A

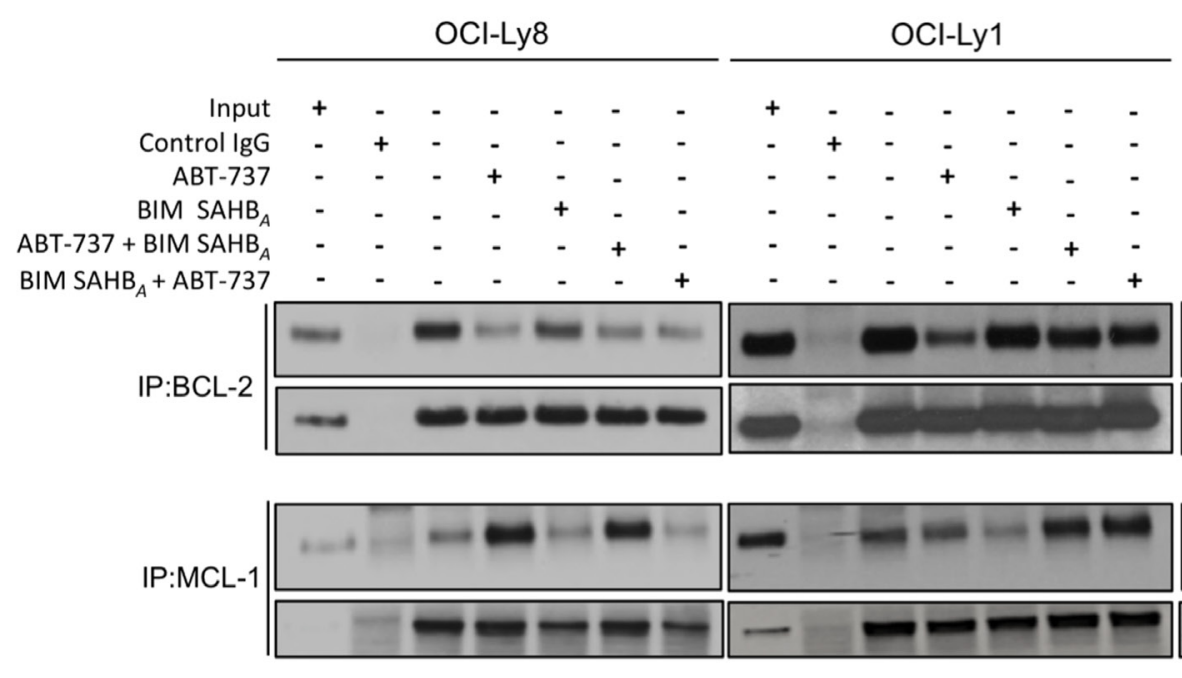

C

\begin{tabular}{lllllll}
\multicolumn{7}{c}{ SU-DHL-6 } \\
\hline+ & - & - & - & - & - & - \\
- & + & - & - & - & - & - \\
- & - & - & + & - & - & - \\
- & - & - & - & + & - & - \\
- & - & - & - & - & + & - \\
- & - & - & - & - & - & + \\
- & & - & - & - & - & - \\
\hline
\end{tabular}

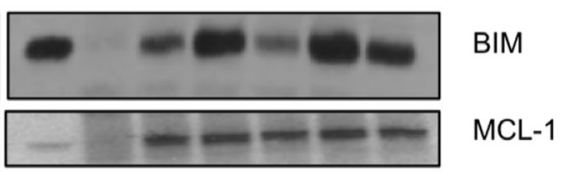

Figure 3: BIM SAHB ${ }_{A}$ preferentially targets MCL-1 over BCL-2 in ABT-737-sensitive DLBCL. (A) OCI-Ly8, (B) OCI-Ly1, and (C) SU-DHL-6 were left untreated (third lane) or treated with ABT-737 (EC ${ }_{50}$; fourth lane), BIM SAHB (EC $_{50}$; fifth lane), ABT-737 for three hours followed by BIM SAHB ${ }_{A}$ for three hours (sixth lane), or BIM SAHB for three hours followed by ABT-737 for three hours (seventh lane). Lysates were immunoprecipitated with antibodies specific for BCL-2, MCL-1, or anti-Rabbit IgG (control), and immune complexes were resolved and immunoblotted for BIM, BCL-2 and MCL-1. Input lysate was loaded in the first lane and immunoprecipitates with a control IgG in the second lane. Treatments: OCI-Ly8: ABT-737 $241 \mathrm{nM}$, BIM SAHB ${ }_{A} 13.2 \mu$ M; OCI-Ly1: ABT-737 30.7 nM, BIM SAHB $A 12 \mu \mathrm{M}$; SU-DHL-6: ABT-737 113 nM, BIM SAHB ${ }_{A} 12 \mu \mathrm{M}$. 


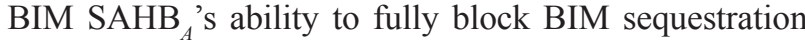
on MCL-1 following treatment with ABT-737 (Figure 4C). Regardless of overall effect, treatment with BIM $\mathrm{SAHB}_{A}$ prior to treatment with ABT-737 at a ratio of 10:1 universally led to increased cell death when compared to the reverse treatment in all cell lines (ABT-737 $\mathrm{EC}_{50}$ : OCI-Ly8: $165 \mathrm{nM}$ to $40.1 \mathrm{nM} \quad(76 \%$ decrease); OCI-Ly1: $93 \mathrm{nM}$ to $66.4 \mathrm{nM}$ (29\% decrease); SU-DHL-6: $100 \mathrm{nM}$ to $63.5 \mathrm{nM}$ (37\% decrease); and SU-DHL-5: $>10,000 \mathrm{nM}$ to $3,360 \mathrm{nM}$ ( $\sim 66 \%$ decrease) (Figure $4 \mathrm{~A}-4 \mathrm{C}$ and Supplementary Figure $3 \mathrm{~B})$. In each case, synergy was observed when BIM $\mathrm{SAHB}_{A}$ was given prior to ABT-737, as reflected by combination indices of less than 0.8 at $50 \%, 75 \%$, and $90 \%$ effective doses. Apart from synergy in OCI-Ly1, ABT-737 treatment prior to BIM SAHB ${ }_{A}$, predominantly resulted in an additive cell killing effect with combination indices between 0.8 and 1.1 [27]. These effects were magnified in OCI-Ly8 at a BIM $\mathrm{SAHB}_{A}$ :ABT-737 ratio of 20:1 where the $\mathrm{EC}_{50}$ decreased from $165 \mathrm{nM}$ to $32.2 \mathrm{nM}$ ( $80 \%$ decrease) and synergy was increased at all effective doses indicating that the amount of BH3 mimetic may play a role in sequential dosing but does not significantly alter synergy values (Figure 4D). The increased sensitivity to ABT-737, particularly in OCI-Ly8, correlated with the ability of MCL-1 to absorb redistributed BIM once released from BCL-2 in these cells. Our results align with previous work showing that normal lymphoid cell and human non-Hodgkin lymphoma resistance to ABT-737 is conferred by mutant BIM specific for BCL-2, BCL-X ${ }_{L}$, and BCL-W [28]. However, mutant BIM specific for MCL-1 led to ABT-737 sensitivity indicating that ABT-737-mediated killing only occurred when MCL-1 was neutralized [28]. Our data would suggest that BIM SAHB is more selective for intracellular MCL-1 and effectively prevents BIM:MCL-1 association in a similar context.

To identify and correlate relevant BCL-2 prosurvival dependency in cells with either high (OCI-Ly8) or low (OCI-Ly1) MCL-1:BIM binding following ABT-737 treatment, we employed lentiviral expression of $\mathrm{BIM}_{\mathrm{S}}$ derived $\mathrm{BH} 3$ variants [29]. These variants can determine biologically relevant $\mathrm{BH} 3$-only protein dependence within an intact cellular environment [30]. OCI-Ly8 and OCI-Ly1 were engineered to inducibly express: 1) BIM $\mathrm{S}_{\mathrm{S}} \mathrm{WT}$ able to target all pro-survival proteins, 2) $\mathrm{BIM}_{\mathrm{S}} 2 \mathrm{~A}$ able to target MCL-1 only, 3) $\mathrm{BIM}_{\mathrm{S}} \mathrm{BAD}$ able to target BCL-2, BCL-X $\mathrm{X}_{\mathrm{L}}$ and BCL-W; or 4) $\mathrm{BIM}_{\mathrm{S}} 4 \mathrm{E}$ unable to bind any anti-apoptotic, serving as a negative control (Supplementary Figure 6) [29]. BIM $\mathrm{S}_{\mathrm{S}} \mathrm{WT}$ expression greatly reduced the viability of both OCI-Ly8 and OCI-Ly1. OCI-Ly8 cells were more sensitive to $\mathrm{BIM}_{\mathrm{S}} \mathrm{BAD}$ compared to $\mathrm{BIM}_{\mathrm{S}} 2 \mathrm{~A}$ indicating more BCL-2 dependence. This anti-apoptotic dependency pattern supports the increased cell death in OCI-Ly8 when treated first with BIM $\mathrm{SAHB}_{A}$ followed by ABT-737 where BIM, released from BCL-2 was unable to reoccupy itself on MCL-1 (Figure 4C). In contrast, targeting of
MCL-1 by BIM $2 \mathrm{~A}$ in OCI-Ly1 led to cell death equal to that of $\mathrm{BIM}_{\mathrm{S}} \mathrm{WT}$ while the response to $\mathrm{BIM}_{\mathrm{S}} \mathrm{BAD}$ was more moderate (Supplementary Figure 5B). Thus, OCI-Ly1 was overall more sensitive to BIM expression in this setting and more dependent on MCL-1 than BCL-2, supporting a different sequestration dynamic when endogenous BIM is dissociated from MCL-1 following BIM $\mathrm{SAHB}_{A}$ treatment. This is despite both DLBCL having similar baseline expression of BCL-2 (Supplementary Figure 2) [10, 11]. Together, these results support that the preferential intracellular target of BIM $\mathrm{SAHB}_{A}$ was MCL-1.

\section{MCL-1 is required for BIM SAHB -dependent $_{A}$ defects in the outer mitochondrial membrane}

Mouse embryonic fibroblasts (MEFs) are dependent upon MCL-1, and to a lesser extent, BCL-X ${ }_{\mathrm{L}}$, for survival [31]. MCL-1 plays the more critical functional role in regulating apoptosis as reflected by the ability of ABT-737 to induce apoptosis only in MCL-1-deficient MEFs [9, 31]. We have previously shown that BIM $\mathrm{SAHB}_{A}$ can induce apoptosis in MCL-1-dependent and ABT-737-resistant malignant hematopoietic cells lines and can dissociate BAK from MCL-1 [17]. We have also shown that BIM $\mathrm{SAHB}_{A}$ can induce cell death in WT MEFs but not in $\mathrm{BAX}^{-/-} \mathrm{BAK}^{-/} \mathrm{MEFs}[16,17]$. To investigate the general

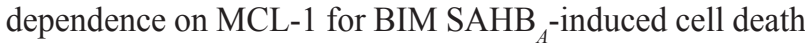
we used MCL-1 ${ }^{-/-} \mathrm{MEF}$ and $\mathrm{MEF}$ s with inducible deletion of MCL-1 (Mcl-1 ${ }^{f f f}$ Rosa-ERCreT2 MEFs) to ensure there was no BCL-2 family compensation secondary to longterm MCL-1 loss [32]. WT and WT Rosa-ERCre T2 MEFs had equivalent expression of MCL-1 and MCL-1 protein was not detectable in either $\mathrm{MCL}-1^{-/}$or $\mathrm{Mcl}-1^{f / f}$ Rosa-ERCreT2 MEFs following treatment with tamoxifen (Figure 5A). Loss of MCL-1 in either MEF allowed for significant apoptosis in response to treatment with ABT-737 (Supplementary Figure 7). ABT-737 induced greater death in $\mathrm{Mcl}^{1 f f}$ Rosa-ERCreT2 MEFs compared to MCL-1 ${ }^{-/}$MEFs likely because MCL- $1^{-/}$MEFs have developed BCL-2 compensatory mechanisms through long-term culturing as has been previously documented in genetic knockout model systems [33, 34]. In contrast

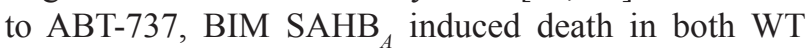
MEFs while either long-term or short-term absence of MCL-1 led to equivalent protection (Figure 5B). Only loss of MCL-1 was responsible for resistance to BIM treatment as indicated by equivalent cell death in $\mathrm{MCL}-1^{-/}$or $\mathrm{Mcl}-1^{f / f}$ Rosa-ERCreT2 MEFs.

We extended these results to investigate if treatment with BIM $\mathrm{SAHB}_{A}$ caused MCL-1-dependent changes in mitochondria morphology. Treatment of WT MEFs with BIM $\mathrm{SAHB}_{A}$ led to cristae disorganization and mitochondrial swelling, hallmarks of intrinsic apoptotic pathway activation (Figure 6A) [35, 36]. These phenotypic changes were not evident in treated $\mathrm{MCL}-1^{-/-} \mathrm{MEFs}$ 
indicating that BIM SAHB ${ }_{A}$ preferentially targets MCL-1 in these cells (Figure 6B). These phenotypic data confirm BIM SAHB ${ }_{A}$ 's ability to target intracellular MCL-1 and supports an MCL-1-dependent mechanism responsible for sensitivity to $\mathrm{BIM} \mathrm{SAHB}_{A}[17]$.

\section{DISCUSSION}

The presence of BCL-2 family anti-apoptotic members dictates cellular sensitivity to $\mathrm{BH} 3$ mimetics. However, expression alone is not enough to predict apoptotic functional dependency patterns, especially as it relates to malignant cell death. This is particularly evident in cells where expression of BCL-2, BCL-X ${ }_{L}$, or BCL-W does not always result in sensitivity to ABT-737 [37-41]. Additionally, ex vivo sensitivity against these agents does not always correlate with long-term in vivo results either in pre-clinical human xenograft studies or in patients
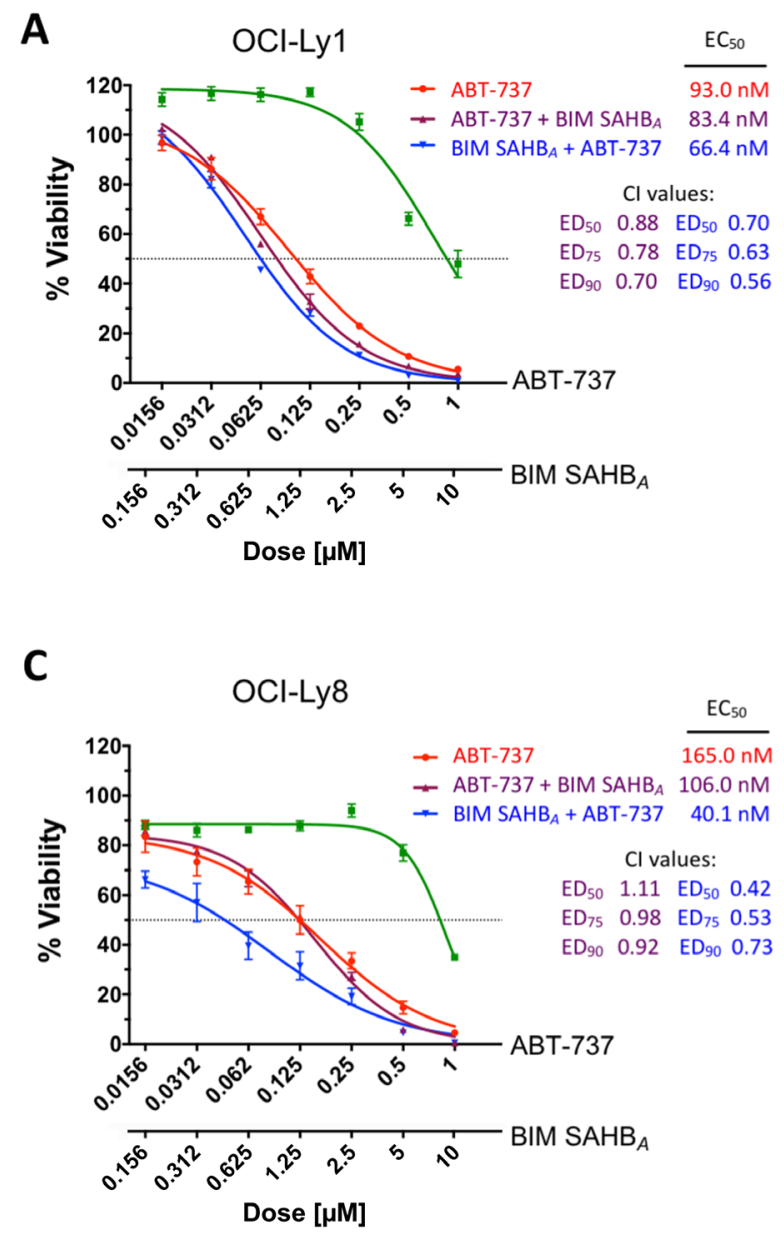

$[25,39]$. A primary reason for these resistance patterns is the up-front presence or emergence of MCL-1 during the course of treatment confirming the dynamism of the BCL-2 family regulatory network [42-44]. Importantly, despite the ability of ABT-737, or its oral analogue

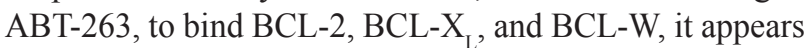
to overwhelmingly bind BCL-2 even when the other antiapoptotics are present $[28,45]$. A recent example of this preferential intracellular attraction is that treatment with ABT-199 or a BCL-X $\mathrm{L}_{\mathrm{L}}$-specific mimetic induced more cell death in BCL-2 and BCL-X $\mathrm{X}_{\mathrm{L}}$ expressing human small cell lung cancer (SCLC) and AML cell lines than treatment with ABT-263, indicating an intracellular preference for either BCL-2 or BCL-X ${ }_{L}$, but not both, by ABT-263 [46]. This phenomenon extends to in vivo testing in SCLC xenograft models where combination treatment with ABT-199 and the BCL-X $\mathrm{L}_{\mathrm{L}}$-specific mimetic resulted in better survival than treatment with ABT-263 alone [46].
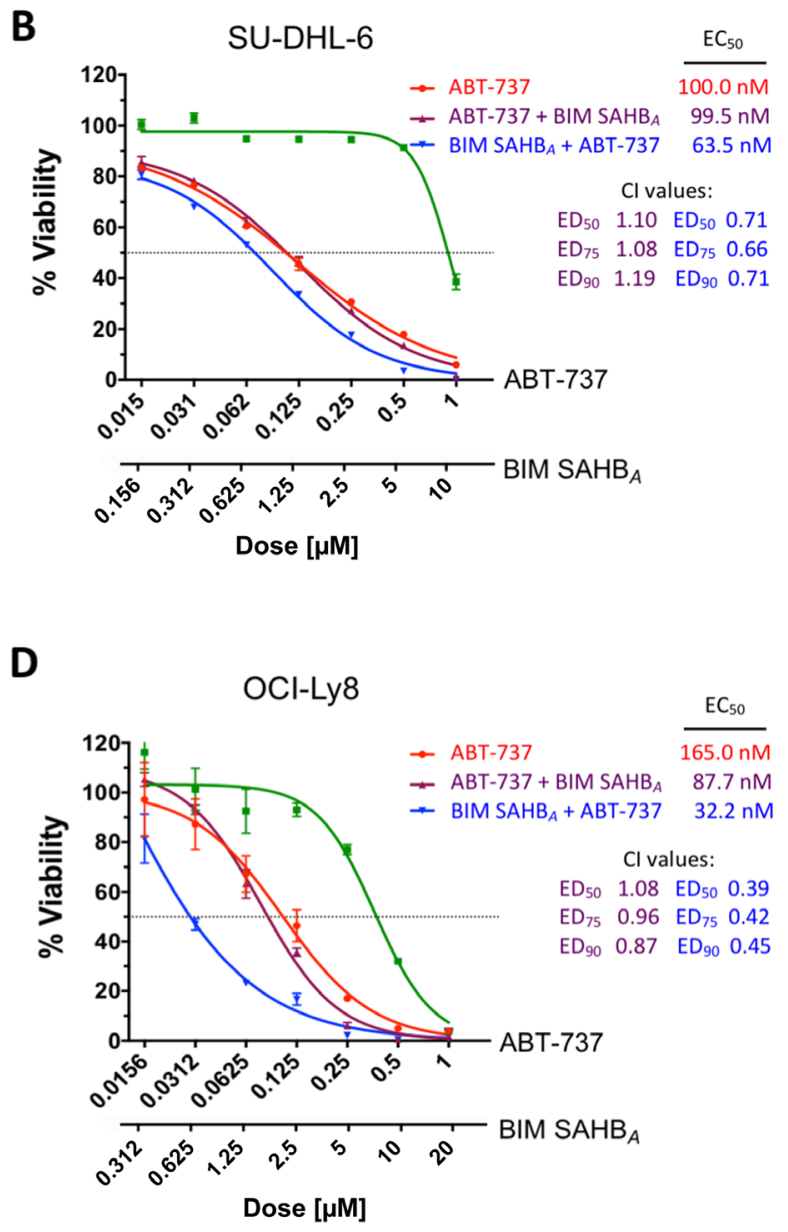

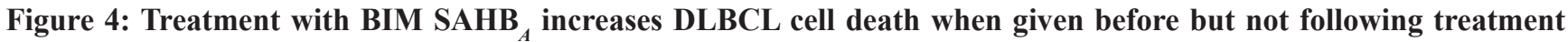
with ABT-737. Cell viability of (A) OCI-Ly1, (B) SU-DHL-6, and (C, D) OCI-Ly8 was measured after 24-hr treatment with increasing

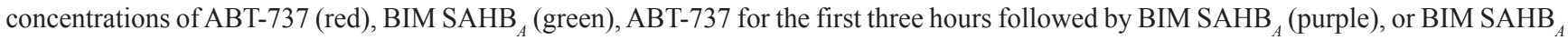
for the first three hours followed by ABT-737 (blue). BIM SAHB ${ }_{A}$ given prior to ABT-737 universally led to a greater synergistic decrease in cell viability, as reflected by CalcuSyn analysis (combination index $[\mathrm{CI}]<1$ ). Error bars are mean $\pm \mathrm{SEM}$ for at least three independent preparations of cells and $\mathrm{BH} 3$ mimetic treatments. $\mathrm{EC}_{50}, 50 \%$ effective concentration; $\mathrm{ED}_{50}, 50 \%$ effective dose; $\mathrm{ED}_{75}, 75 \%$ effective dose; $\mathrm{ED}_{90}, 90 \%$ effective dose. 
Adding to the difficulty in navigating the BCL-2 targeting landscape, cancers derived from the same cell type can show different BCL-2 anti-apoptotic dependencies [10, 40, 41, 46, 47]. These differences often relate to levels of BIM expression and patterns of BIM:anti-apoptotic sequestration [47]. DLBCL is an example of such a disease where cell death resistance depends upon combinations of BIM bound to a number of antiapoptotics (BCL-2, BCL- $\mathrm{X}_{\mathrm{L}}$, and MCL-1), and is therefore a useful model for testing the importance of both anti-apoptotic expression and BIM:anti-apoptotic sequestration differences relating to BH3-mimetic sensitivity [10-12, 25].

Like other $\mathrm{BH} 3$ mimetics, quantitative expression levels of BCL-2 proteins alone were not effective indicators of sensitivity to BIM SAHB ${ }_{A}$. However, given the natural affinity of the $\mathrm{BIM} \mathrm{BH} 3$ death domain to engage all anti- and pro-apoptotic BCL-2 proteins, it was not surprising that the cell permeable hydrocarbon-stapled BIM BH3 therapeutic reactivated cell death in all DLBCL

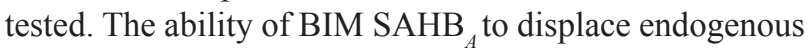
BIM from BCL-2 and MCL-1 supports the promise of the BIM BH3 domain as a therapeutic. Unexpectedly, like ABT-737/ABT-263 intracellular affinity for BCL-2 in many disease models, BIM $\mathrm{SAHB}_{A}$ has a propensity for targeting intracellular MCL-1 over BCL-2. This was likely responsible for its inverse sensitivity profile against the DLBCL cell lines compared to that of ABT-737 and ABT-199. In this regard, a therapeutic with BIM SAHB ${ }_{A}$ 's

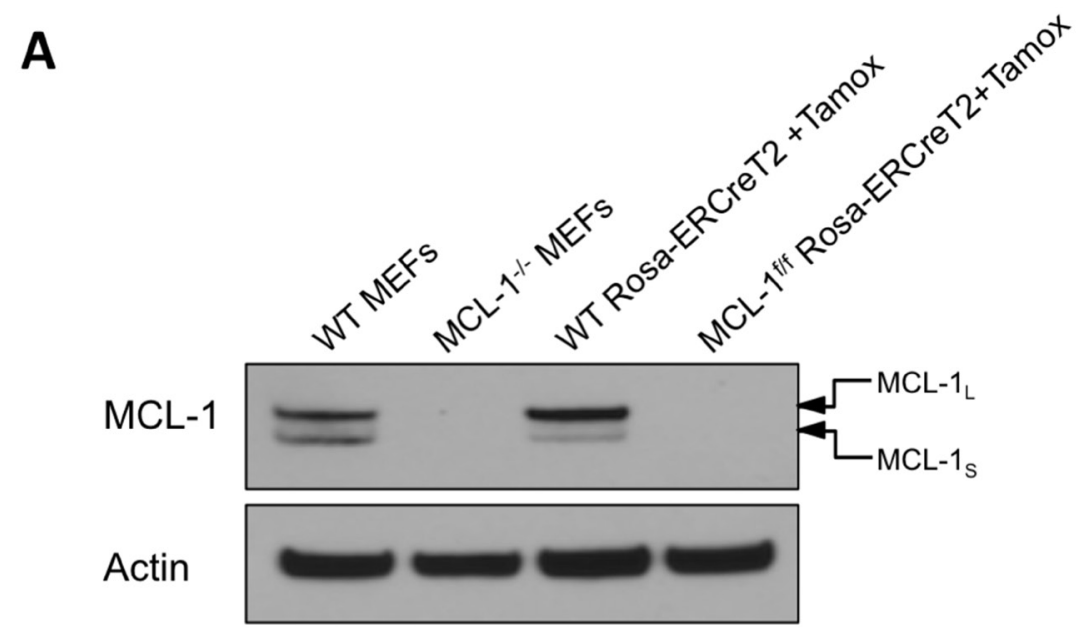

B

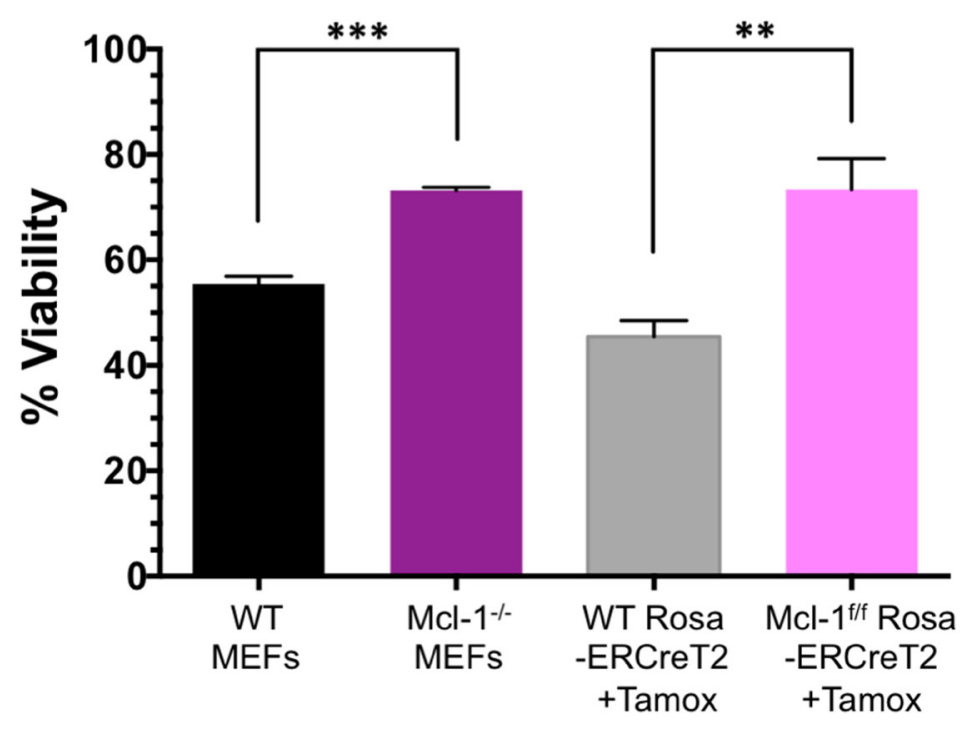

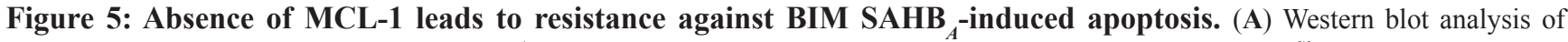
MCL-1 expression in WT MEFs and MCL-1 ${ }^{-/}$MEFs at steady-state and Rosa-ERCreT2 control MEFs and Mcl-1 ${ }^{\text {fff }}$ Rosa-ERCreT2 MEFs 72-hr following treatment with $100 \mathrm{nM}$ of (4-hydroxy)-tamoxifen. Equivalent presence of MCL-1 was measured in the control MEFs and complete loss of MCL-1 was measured in MCL-1 ${ }^{-/}$and Mcl-1 ${ }^{\text {fff }}$ Rosa-ERCreT2 MEFs. Short (S) and long (L) isoforms of MCL-1 are indicated by arrows. (B) Cell viability of these MEFs was measured following 24-hr treatment with $20 \mu \mathrm{M}$ BIM SAHB . Error bars are mean \pm SEM for at least three independent preparations of cells and $\mathrm{BH} 3$ mimetic treatments. 
therapeutic profile could be of particular benefit against activated B-cell like (ABC) DLBCLs that express MCL1 at higher levels and have higher MCL-1:BIM binding than germinal center B-cell like (GCB) DLBCL [12]. However, despite the single agent efficacy of BIM SAHB Saginst $_{A}$ DLBCL as shown here, combination BH3 mimetic therapy will likely be necessary for reactivation of cell death at clinically useful levels [47-49]. Our data would also suggest that dosing and the sequence of such therapies are critical.

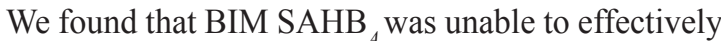
dissociate a large amount of released endogenous BIM following treatment with ABT-737 when MCL-1 was present. However, prior to release from BCL-2, BIM $\mathrm{SAHB}_{A}$ was able to efficiently bind MCL-1 and prevent relocation of BIM in the more $\mathrm{BCL}-2$-dependent and lower MCL-1 expressing cell lines (Figure 3A and 3C). It should be noted that DLBCL were treated at their $\mathrm{EC}_{50}$ in our study so as to capture cells before they underwent complete apoptosis. Additional studies will be needed to determine if increased doses of BIM SAHB ${ }_{A}$, as used in Figure 4D, or various treatment times would adequately remove BIM from DLBCL with larger amounts of MCL-1 following treatment with ABT-737 or ultimately stabilize MCL-1 protein levels as do newly introduced high-affinity small molecule MCL-1 inhibitors [6, 50]. In addition to dosing amounts, the timing of death induced by such treatments, either alone or in combination, likely differ between cell lines. Such differences could also be reflected in the relative amount of caspase $3 / 7$ activation

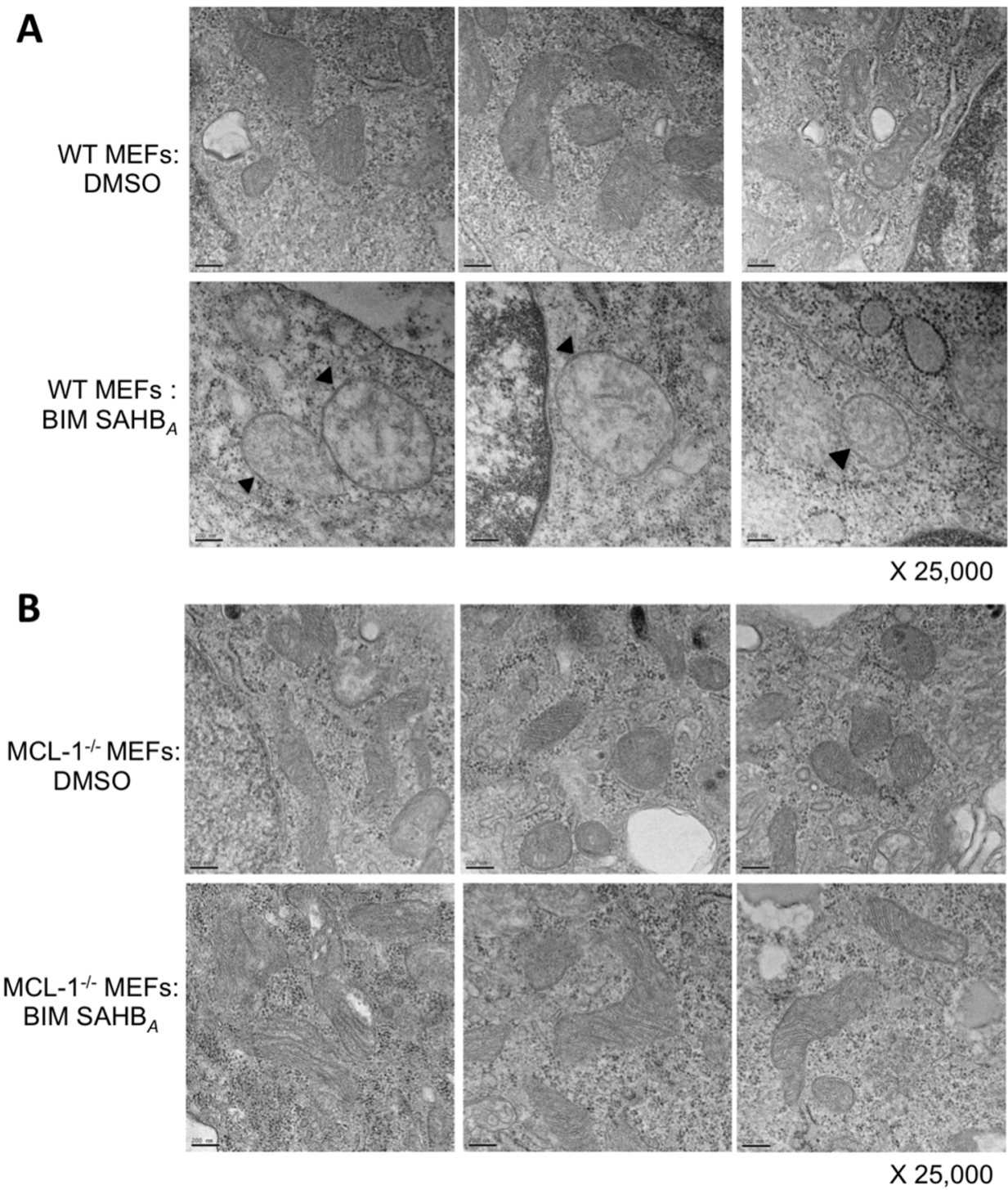

Figure 6: BIM SAHB ${ }_{A}$ induces characteristic hallmarks of apoptosis at the level of the mitochondria in the presence

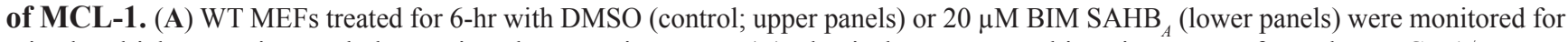
mitochondrial apoptotic morphology using electron microscopy. (B) Identical treatment and imaging was performed on MCL-1 ${ }^{-/}$MEFs.

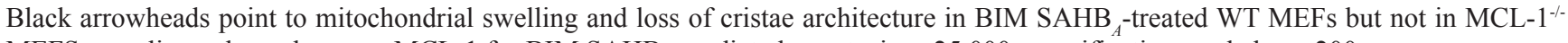
MEFS revealing a dependence on MCL-1 for BIM SAHB ${ }_{A}$-mediated apoptosis. x 25,000 magnification; scale bars, $200 \mathrm{~nm}$. 
(Figure 2A) or synergy calculations in these and other cell lines where such combination treatments have been tested $[11,13,14,51]$. Additionally, this work does not rule out the possibility of simultaneous triggering of caspase-dependent (e.g. apoptosome/caspase 3 and endonuclease activity) and caspase-independent (e.g. AIF) pathways following BIM $\mathrm{SAHB}_{A}$ treatment and caspase $3 / 7$ activation. Despite this, the current study reinforces work indicating that the ability of $\mathrm{BH} 3$ mimetics to preferentially target intracellular BCL-2 antiapoptotic members often does not completely reflect their in vitro binding profile(s) $[4,10,28,45]$. We and others have shown that BIM SAHB binds MCL-1, BCL-X $_{L}$, $\mathrm{BCL}-2$, and $\mathrm{A} 1$ with low nanamolar affinity and is able to dissociate $\mathrm{BAK}$ and $\mathrm{BAX} \mathrm{BH} 3$ ligands from MCL-1 and $\mathrm{BCL}-\mathrm{X}_{\mathrm{L}}$ respectively $[17,52]$. Although able to bind all anti-apoptotics tested, the current study supports that the preferential intracellular target of BIM $\mathrm{SAHB}_{A}$ is MCL-1 over BCL-2, at least in DLBCL. However, we cannot discount that direct activation of $\mathrm{BAX}$ or dissociation of other $\mathrm{BH} 3$-only proteins, such as BID, plays a role in the overall cell death effectiveness of BIM $\mathrm{SAHB}_{A}$ in these same cells $[16,17,26,52]$.

Well-timed combination $\mathrm{BH} 3$ mimetic therapy may be a promising strategy against diseases like DLBCL where oncoproteins (e.g. MYC, BCL6, and BCL-2) play roles in blocking the intrinsic apoptotic network through direct upregulation of BCL-2 family members and other cell death-related proteins [53, 54]. Such complex perturbation in apoptotic regulation necessitates a combinatorial therapeutic approach involving multiple BH3 mimetics, which may include small molecule and peptide-based therapeutics, alone or with other conventional chemotherapies. A complete understanding of intracellular affinities and the therapeutic ramifications of targeted anti-apoptotic therapeutics on relocation of BIM will be critical as BH3-mimetic therapies are advanced.

\section{MATERIALS AND METHODS}

\section{Cell culture and therapeutic reagents}

Human DLBCL cell lines (kind gift from Margaret A. Shipp, M.D., Dana-Farber Cancer Institute, Boston, MA 02115, USA and purchased from ATCC and DSMZ) were cultured in RPMI 1640 medium supplemented with $0.5 \mathrm{mg} / \mathrm{ml}$ penicillin/streptomycin, $2 \mathrm{mM}$ L Glutamine, $1 \mathrm{mM}$ HEPS, Non-Essential Amino Acids (all from Life technologies) and 10\% heat inactivated fetal bovine serum (Denville Scientific). HEK293T were obtained from American Type Culture Collection. HEK293T cells and MEFs Cells were grown in Dulbecco's modified Eagle's medium (DMEM, Life technologies) supplemented with same reagents as previously mentioned. For BIM $\mathrm{SAHB}_{A}$ treatment, cells were cultured in advanced RPMI supplemented with $0.5 \mathrm{mg} / \mathrm{ml}$ penicillin/streptomycin, $2 \mathrm{mM}$ L Glutamine, $1 \mathrm{mM}$ HEPS, 1\% NEAA. All cells were maintained at $37^{\circ} \mathrm{C}$ in $5 \% \mathrm{CO}_{2}$. Wild-type ERCreT2 and Mcl-1f/f Rosa-ERCreT2 MEFs were a kind gift from Joseph T. Opferman Ph.D., St. Jude Children's Research Hospital. BIM SAHB SA BIM SAHB $_{A}$ (R153D) were synthesized, purified, as previously reported [16, 17, 19]. SAHB constructs used in caspase assays and confocal cell death assays were a kind gift from Loren D. Walensky, M.D., Ph.D. and Gregory Bird, Ph.D., Dana-Farber Cancer Institute, Boston, MA. All other SAHBs used for cell treatments were synthesized at the University of Chicago. Doxycycline (Sigma), ABT-199 (Selleck Chemicals), ABT737 (Selleck Chemicals), (4-hydroxy)-tamoxifen (Sigma).

\section{Viability assays}

DLBCL $\left(2 \times 10^{4}\right.$ cells $)$ were treated with serial dilutions of BIM $\mathrm{SAHB}_{A}$, ABT-199, ABT-737 or DMSO for $2 \mathrm{~h}$ in serum free advanced RPMI media followed by addition of FBS to the media (to $10 \%[\mathrm{v} / \mathrm{v}]$ ) as previously described [17]. Viability was assessed using Cell proliferation kit II XTT (Roche) according to the manufacturer's instructions. Absorbance $\mathrm{EC}_{50} \mathrm{~S}$ were calculated using GraphPad Prism 6 software. For combination treatments, DLBCL $\left(2 \times 10^{4}\right.$ cells $)$ were treated with serial dilutions of BIM SAHB $(0-20 \mu \mathrm{M})$ or ABT-737 (0-1 or to $20 \mu \mathrm{M}), 3 \mathrm{~h}$ in serum free advanced RPMI media followed by $3 \mathrm{~h}$ of treatment with either

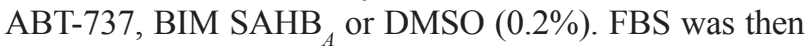
added to the media (to $10 \%[\mathrm{v} / \mathrm{v}]$ ). Viability was assessed $24 \mathrm{~h}$ later using CellTiter-Glo according to the manufacturer's instructions. (XTT) or luminescence (CellTiter-Glo) was detected by Synergy 2 microplate reader (BioTek). Synergy analyses were performed as previously described [17].

\section{Caspase-3/7 activation assay}

DLBCL (10,000 cells/well) were seeded in 96well plates in advanced RPMI Growth Media and were treated with BIM SAHB $A$ or DMSO for 6 hours. CaspaseGlo 3/7 chemiluminescence reagent (Promega) was used according to manufacturer's directions. Luminescence was measured by a Synergy 2 microplate reader (BioTek) and was standardized to DMSO treated samples as previously described [17].

\section{Western blot analysis}

Following treatment of individual DLBCL with compounds, cells were washed with PBS and lysed in cell lysis buffer ( $25 \mathrm{mM}$ HEPES pH 7.5, $150 \mathrm{mM} \mathrm{NaCl}$, $1 \%$ Triton X-100, 0.1\% SDS, $5 \mathrm{mM}$ EDTA and $1 \mathrm{mM}$ $\mathrm{NaF}$ supplemented with $1 \mathrm{x}$ protease inhibitor cocktail tablets [Roche]) as previously described [17]. Protein concentrations were determined by Pierce BCA Protein 
Assay Kit (Thermo Scientific). $30 \mu \mathrm{g}$ of protein were electrophoretically separated on NuPAGE $12 \%$ Bis-Tris polyacrylamide gels (Invitrogen). Separated proteins were transferred to nitrocellulose membranes (BioRad). Blots were incubated with the following antibodies: MCL-1 (Santa Cruz, S-19), BCL-2 (Epitomics, 1017-1), BCL-X (Santa Cruz, S18), BIM (Millipore AB17003), BAX (Santa Cruz, N20), BAK (Millipore 06-536), BID (Santa Cruz), GAPDH (Santa Cruz FL-335), PUMA (Santa Cruz). The immune complex was detected using anti-rabbit HRP-conjugated antibody (Envision Detection Kit, DakoCytomation) and the chemiluminescent detection kit according to the manufacturer's specifications (Amersham). Proteins were visualized with $C L$-XPosure Film (Thermo Scientific) using AX200 X-Ray film processor (Aphatek).

\section{Immunoprecipitation}

DLBCL $\left(9 \times 10^{6}\right.$ cells $)$ were lysed in $2 \mathrm{ml}$ of Triton $\mathrm{X}-100$ buffer $(50 \mathrm{mM}$ Tris-HCL [pH 7.4], $150 \mathrm{mM}$ $\mathrm{NaCl}, 5 \mathrm{mM} \mathrm{MgCl} 2,1 \mathrm{mM}$ EGTA, 10\% Glycerol, $1 \%$ Triton X-100 and $1 \mathrm{x}$ protease inhibitor cocktail tablets [Roche]) on ice for $30 \mathrm{~min}$ and then centrifuged at 18,000 $\times \mathrm{g}$ for $20 \mathrm{~min}$ at $4^{\circ} \mathrm{C} .400 \mu \mathrm{g}$ proteins was pre-cleared using $30 \mu \mathrm{l}$ of Pierce Protein A Magnetic Beads (Thermo Scientific) for 2 hours at $4^{\circ} \mathrm{C}$ then incubated overnight at $4^{\circ} \mathrm{C}$ with MCL-1 antibody (Protein Tech, 16225), BCL-2 antibody (Epitomics, 1017-1) or Rabbit IgG. $20 \mu \mathrm{l}$ of Magnetic beads were added and incubated for 2 hours. Immunoprecipitates were then washed 5 times with $500 \mu \mathrm{l}$ of Triton X-100 buffer and boiled in NuPAGE LDS Sample Buffer (Thermo Scientific) supplemented with $1 \mathrm{mM}$ DTT and proteins were separated on NuPAGE $10 \%$ Bis-Tris polyacrylamide gels.

\section{Wright-giemsa stain}

DLBCL cells were treated with vehicle or BIM $\mathrm{SAHB}_{A}$ in Opti-MEM media for 4 hours at $37^{\circ} \mathrm{C}$. Cells stained as previously described [17]. Briefly, cells were collected and washed twice with PBS containing 2\% FBS and resuspended at $2.5 \times 10^{6}$ cells $/ \mathrm{ml}$ for mounting of the cellular suspension onto glass slides by cytospin. The slides were air dried and then stained with Accustain Modified Wright-Giemsa according to the manufacturer's protocol (Sigma-Aldrich).

\section{$\mathrm{BIM}_{\mathrm{s}}$ isoform lentivirus production and transduction}

The TRIPZ vectors with inducible expression of the different variants of $\mathrm{BIM}_{\mathrm{s}}$ were a kind gift from Andreas Strasser, Ph.D. (The Walter and Eliza Hall Institute, Parkville, Melbourne) [29]. To generate cells stably expressing the inducible $\mathrm{BIM}_{\mathrm{s}}$ variants, DLBCL cells were infected with viral supernatants, produced by lipofectamine 2000 co-transfection of 293T cells with
TRIPZ expression constructs and packaging plasmids according to the manufacture protocol and as previously described [29]. Cells were expanded then FACS-sorted for the expression of GFP using a BD FACSAria cell sorter. The expression of BIMs proteins was induced as previously described [29].

\section{Electron microscopy}

Indicated MEFs were plated in six-well format $\left(2 \times 10^{5}\right.$ cell/condition) were washed in serum free Advanced DMEM following overnight induction. The cells were then incubated with $20 \mu \mathrm{M}$ BIM SAHB or vehicle $(0.05 \%[\mathrm{v} / \mathrm{v}] \mathrm{DMSO})$ for $2-\mathrm{hr}$, and then FBS was added for an additional 4-hr. The cells were washed twice with advanced DMEM media and fixed in the dish using a solution of $2 \%(\mathrm{w} / \mathrm{v})$ glutaraldehyde, $4 \%(\mathrm{w} / \mathrm{v})$ paraformaldehyde, in $0.1 \mathrm{M}$ sodium cacodylate buffer overnight at RT. The cells were then washed in $0.1 \mathrm{M}$ sodium cacodylate buffer ( $\mathrm{pH} 7.4) 3 \mathrm{X} 5 \mathrm{~min}$, post-fixed for $60 \mathrm{~min}$ in $1 \%(\mathrm{w} / \mathrm{v}) 1 \%$ Osmium Tetroxide in $0.1 \mathrm{M}$ sodium cacodylate buffer, washed in sodium cacodylate buffer 2X5 min and Maleate buffer (pH5.1) once, $5 \mathrm{~min}$, and then incubated in $1 \%(\mathrm{w} / \mathrm{v})$ aqueous uranyl acetate in Maleate buffer for $60 \mathrm{~min}$, followed wash in Maleate buffer $3 X 5 \mathrm{~min}$. The cells were removed from the dish in 2:1 propylene oxide and incubated overnight in a 1:1 mixture of propylene oxide. The samples were subsequently embedded in TAAB Epon and polymerized at $60^{\circ} \mathrm{C}$ for $48 \mathrm{~h}$. Ultrathin sections $(\sim 90 \mathrm{~nm})$ were cut on a Reichert-Jung Ultracut $\mathrm{E}$ microtome, placed onto copper grids, stained with Uranyl acetate and Lead citrate, and then examined under 300KV at FEI Tecnai F30 and the Gatan CCD digital micrograph. Electron microscopic sample preparation and imaging was performed in conjunction with the Advanced Electron Microscopy facility at the University of Chicago.

\section{Abbreviations}

ABC: activated B-cell; CCD: charge-coupled device; DLBCL: diffuse large B-cell lymphoma; DMEM: Dulbecco's modified Eagle medium; DMSO: dimethyl sulfoxide; DTT: dithiothreitol; EC50: halfmaximal concentration of drug; EGTA: ethylene glycolbis( $\beta$-aminoethyl)-N,N,N',N'-tetraacetic acid; FACS: fluorescence-activated cell sorter; GCB: germinal center B-cell; GFP: green-fluorescent protein; HEPES: 4-(2-hydroxyethyl)-1-piperazineethanesulfonic acid; $\mathrm{Hr}$ : hour; MEF: mouse embryonic fibroblast; Min: minute; mM: millimolar; MOMP: mitochondrial outer membrane permeabilization; NEAA: non-essential amino acids; nM: nanomolar; PAGE: polyacrylamide gel electrophoresis; PBS: phosphate buffered saline; RPMI: Roswell Park Memorial Institute medium; RT: room temperature; SDS: sodium dodecyl sulfate; SEM: standard error of the mean; $\mu \mathrm{M}$ : micromolar; WT: wild-type. 


\section{Author contributions}

$\mathrm{AH}$ - study design, data acquisition, data analysis and interpretation, drafting manuscript, final approval of manuscript; GKS - data acquisition, data analysis and interpretation, final approval of manuscript; MRS acquisition of data, chemical engineering of compounds, final approval of manuscript; LR - acquisition of data, data analysis and interpretation, final approval of manuscript; MVT - data analysis and interpretation, final approval of manuscript; JLL - study design, data analysis and interpretation, drafting manuscript, final approval of manuscript.

\section{ACKNOWLEDGMENTS}

The authors would like to thank the laboratories of Loren D. Walensky, Joseph T. Opferman, and Margaret A. Shipp for graciously providing the cell lines and initial SAHB constructs, the laboratory of Andreas Strasser for the lentiviral Bim vectors, and the Advanced Electron Microscopy facility at the University of Chicago for assistance in acquiring the TEM images used in this study.

\section{CONFLICTS OF INTEREST}

The authors report no conflicts of interest.

\section{FUNDING}

This work was supported by the National Institutes of Health (NIH) K08-CA151450 (JLL) and the Cancer Research Foundation (JLL). Additional support was provided by the National Center for Advancing Translational Sciences of the National Institutes of Health through Grant Number UL1 TR000430.

\section{REFERENCES}

1. Czabotar PE, Lessene G, Strasser A, Adams JM. Control of apoptosis by the BCL-2 protein family: implications for physiology and therapy. Nat Rev Mol Cell Biol. 2014; 15:49-63. https://doi.org/10.1038/nrm3722. [PubMed]

2. Delbridge AR, Grabow S, Strasser A, Vaux DL. Thirty years of BCL-2: translating cell death discoveries into novel cancer therapies. Nat Rev Cancer. 2016; 16:99-109. https:// doi.org/10.1038/nrc.2015.17. [PubMed]

3. Renault TT, Elkholi R, Bharti A, Chipuk JE. B cell lymphoma-2 (BCL-2) homology domain 3 (BH3) mimetics demonstrate differential activities dependent upon the functional repertoire of pro- and anti-apoptotic BCL-2 family proteins. J Biol Chem. 2014; 289:26481-91. https:// doi.org/10.1074/jbc.M114.569632. [PubMed]

4. Varadarajan S, Vogler $M$, Butterworth $M$, Dinsdale D, Walensky LD, Cohen GM. Evaluation and critical assessment of putative MCL-1 inhibitors. Cell Death Differ. 2013; 20:1475-84. https://doi.org/10.1038/cdd.2013.79. [PubMed]

5. Vogler M, Weber K, Dinsdale D, Schmitz I, Schulze-Osthoff K, Dyer MJ, Cohen GM. Different forms of cell death induced by putative BCL2 inhibitors. Cell Death Differ. 2009; 16:1030-9. https://doi.org/10.1038/cdd.2009.48. [PubMed]

6. Leverson JD, Zhang H, Chen J, Tahir SK, Phillips DC, Xue J, Nimmer P, Jin S, Smith M, Xiao Y, Kovar P, Tanaka A, Bruncko M, et al. Potent and selective small-molecule MCL-1 inhibitors demonstrate on-target cancer cell killing activity as single agents and in combination with ABT-263 (navitoclax). Cell Death Dis. 2015; 6:e1590. https://doi. org/10.1038/cddis.2014.561. [PubMed]

7. Pécot J, Maillet L, Le Pen J, Vuillier C, Trécesson SC, Fétiveau A, Sarosiek KA, Bock FJ, Braun F, Letai A, Tait SWG, Gautier F, Juin PP. Tight Sequestration of BH3 Proteins by BCL-xL at Subcellular Membranes Contributes to Apoptotic Resistance. Cell Rep. 2016; 17:3347-58. https://doi.org/10.1016/j.celrep.2016.11.064. [PubMed]

8. Tahir SK, Yang X, Anderson MG, Morgan-Lappe SE, Sarthy AV, Chen J, Warner RB, Ng SC, Fesik SW, Elmore $\mathrm{SW}$, Rosenberg SH, Tse C. Influence of Bcl-2 family members on the cellular response of small-cell lung cancer cell lines to ABT-737. Cancer Res. 2007; 67:1176-83. https://doi.org/10.1158/0008-5472.CAN-06-2203. [PubMed]

9. van Delft MF, Wei AH, Mason KD, Vandenberg CJ, Chen L, Czabotar PE, Willis SN, Scott CL, Day CL, Cory S, Adams JM, Roberts AW, Huang DC. The BH3 mimetic ABT-737 targets selective $\mathrm{Bcl}-2$ proteins and efficiently induces apoptosis via Bak/Bax if Mcl-1 is neutralized. Cancer Cell. 2006; 10:389-99. https://doi.org/10.1016/j.ccr.2006.08.027. [PubMed]

10. Deng J, Carlson N, Takeyama K, Dal Cin P, Shipp M, Letai A. BH3 profiling identifies three distinct classes of apoptotic blocks to predict response to ABT-737 and conventional chemotherapeutic agents. Cancer Cell. 2007; 12:171-85. https://doi.org/10.1016/j.ccr.2007.07.001. [PubMed]

11. Phillips DC, Xiao Y, Lam LT, Litvinovich E, RobertsRapp L, Souers AJ, Leverson JD. Loss in MCL-1 function sensitizes non-Hodgkin's lymphoma cell lines to the BCL2-selective inhibitor venetoclax (ABT-199). Blood Cancer J. 2015; 5:e368. https://doi.org/10.1038/bcj.2015.88. [PubMed]

12. Wenzel SS, Grau M, Mavis C, Hailfinger S, Wolf A, Madle H, Deeb G, Dörken B, Thome M, Lenz P, Dirnhofer S, Hernandez-Ilizaliturri FJ, Tzankov A, et al. MCL1 is deregulated in subgroups of diffuse large B-cell lymphoma. Leukemia. 2013; 27:1381-90. https://doi.org/10.1038/ leu.2012.367. [PubMed]

13. Klanova M, Andera L, Brazina J, Svadlenka J, Benesova S, Soukup J, Prukova D, Vejmelkova D, Jaksa R, Helman K, Vockova P, Lateckova L, Molinsky J, et al. 
Targeting of BCL2 Family Proteins with ABT-199 and Homoharringtonine Reveals BCL2- and MCL1-Dependent Subgroups of Diffuse Large B-Cell Lymphoma. Clin Cancer Res. 2016; 22:1138-49. https://doi.org/10.1158/1078-0432. CCR-15-1191. [PubMed]

14. Li L, Pongtornpipat P, Tiutan T, Kendrick SL, Park S, Persky DO, Rimsza LM, Puvvada SD, Schatz JH. Synergistic induction of apoptosis in high-risk DLBCL by BCL2 inhibition with ABT-199 combined with pharmacologic loss of MCL1. Leukemia. 2015; 29:1702-12. https://doi. org/10.1038/leu.2015.99. [PubMed]

15. Mérino D, Giam M, Hughes PD, Siggs OM, Heger K, O'Reilly LA, Adams JM, Strasser A, Lee EF, Fairlie WD, Bouillet $\mathrm{P}$. The role of $\mathrm{BH} 3$-only protein Bim extends beyond inhibiting Bcl-2-like prosurvival proteins. J Cell Biol. 2009; 186:355-62. https://doi.org/10.1083/jcb.200905153. [PubMed]

16. Edwards AL, Wachter F, Lammert M, Huhn AJ, Luccarelli J, Bird GH, Walensky LD. Cellular Uptake and Ultrastructural Localization Underlie the Pro-apoptotic Activity of a Hydrocarbon-stapled BIM BH3 Peptide. ACS Chem Biol. 2015; 10:2149-57. https://doi.org/10.1021/ acschembio.5b00214. [PubMed]

17. LaBelle JL, Katz SG, Bird GH, Gavathiotis E, Stewart ML, Lawrence C, Fisher JK, Godes M, Pitter K, Kung AL, Walensky LD. A stapled BIM peptide overcomes apoptotic resistance in hematologic cancers. J Clin Invest. 2012; 122:2018-31. https://doi.org/10.1172/JCI46231. [PubMed]

18. Reynolds C, Roderick JE, LaBelle JL, Bird G, Mathieu R, Bodaar K, Colon D, Pyati U, Stevenson KE, Qi J, Harris M, Silverman LB, Sallan SE, et al. Repression of BIM mediates survival signaling by MYC and AKT in highrisk T-cell acute lymphoblastic leukemia. Leukemia. 2014; 28:1819-27. https://doi.org/10.1038/leu.2014.78. [PubMed]

19. Bird GH, Gavathiotis E, LaBelle JL, Katz SG, Walensky LD. Distinct BimBH3 (BimSAHB) stapled peptides for structural and cellular studies. ACS Chem Biol. 2014; 9:831-7. https://doi.org/10.1021/cb4003305. [PubMed]

20. Bai M, Skyrlas A, Agnantis NJ, Kamina S, Tsanou E, Grepi C, Galani V, Kanavaros P. Diffuse large B-cell lymphomas with germinal center B-cell-like differentiation immunophenotypic profile are associated with high apoptotic index, high expression of the proapoptotic proteins bax, bak and bid and low expression of the antiapoptotic protein bcl-xl. Mod Pathol. 2004; 17:847-56. https://doi.org/10.1038/modpathol.3800130. [PubMed]

21. Bosch R, Dieguez-Gonzalez R, Céspedes MV, Parreño M, Pavón MÁ, Grañena A, Sierra J, Mangues R, Casanova I. A novel inhibitor of focal adhesion signaling induces caspaseindependent cell death in diffuse large B-cell lymphoma. Blood. 2011; 118:4411-20. https://doi.org/10.1182/ blood-2011-04-345181. [PubMed]

22. Fitzsimmons L, Boyce AJ, Wei W, Chang C, Croom-Carter D, Tierney RJ, Herold MJ, Bell AI, Strasser A, Kelly GL, Rowe M. Coordinated repression of BIM and PUMA by
Epstein-Barr virus latent genes maintains the survival of Burkitt lymphoma cells. Cell Death Differ. 2018; 25:241-254. https://doi.org/10.1038/cdd.2017.150. [PubMed]

23. Inomata $\mathrm{M}$, Tagawa $\mathrm{H}$, Guo YM, Kameoka Y, Takahashi N, Sawada K. MicroRNA-17-92 down-regulates expression of distinct targets in different B-cell lymphoma subtypes. Blood. 2009; 113:396-402. https://doi.org/10.1182/ blood-2008-07-163907. [PubMed]

24. Adams CM, Mitra R, Gong JZ, Eischen CM. Non-Hodgkin and Hodgkin Lymphomas Select for Overexpression of BCLW. Clin Cancer Res. 2017; 23:7119-29. https://doi. org/10.1158/1078-0432.CCR-17-1144. [PubMed]

25. Konopleva M, Pollyea DA, Potluri J, Chyla B, Hogdal L, Busman T, McKeegan E, Salem AH, Zhu M, Ricker JL, Blum W, DiNardo CD, Kadia T, et al. Efficacy and Biological Correlates of Response in a Phase II Study of Venetoclax Monotherapy in Patients with Acute Myelogenous Leukemia. Cancer Discov. 2016; 6:1106-17. https://doi.org/10.1158/2159-8290.CD-16-0313. [PubMed]

26. Gavathiotis E, Suzuki M, Davis ML, Pitter K, Bird GH, Katz SG, Tu HC, Kim H, Cheng EH, Tjandra N, Walensky LD. BAX activation is initiated at a novel interaction site. Nature. 2008; 455:1076-81. https://doi.org/10.1038/nature07396. [PubMed]

27. Bijnsdorp IV, Giovannetti E, Peters GJ. Analysis of drug interactions. Methods Mol Biol. 2011; 731:421-34. https:// doi.org/10.1007/978-1-61779-080-5 34. [PubMed]

28. Mérino D, Khaw SL, Glaser SP, Anderson DJ, Belmont LD, Wong C, Yue P, Robati M, Phipson B, Fairlie WD, Lee EF, Campbell KJ, Vandenberg CJ, et al. Bcl-2, Bcl-x(L), and $\mathrm{Bcl}-\mathrm{w}$ are not equivalent targets of ABT-737 and navitoclax (ABT-263) in lymphoid and leukemic cells. Blood. 2012; 119:5807-16. https://doi.org/10.1182/blood-2011-12-400929. [PubMed]

29. Glaser SP, Lee EF, Trounson E, Bouillet P, Wei A, Fairlie WD, Izon DJ, Zuber J, Rappaport AR, Herold MJ, Alexander WS, Lowe SW, Robb L, et al. Anti-apoptotic Mcl-1 is essential for the development and sustained growth of acute myeloid leukemia. Genes Dev. 2012; 26:120-5. https://doi.org/10.1101/gad.182980.111. [PubMed]

30. Lopez J, Bessou M, Riley JS, Giampazolias E, Todt F, Rochegue T, Oberst A, Green DR, Edlich F, Ichim G, Tait SW. Mito-priming as a method to engineer Bcl-2 addiction. Nat Commun. 2016; 7:10538. https://doi.org/10.1038/ ncomms 10538. [PubMed]

31. White MJ, McArthur K, Metcalf D, Lane RM, Cambier JC, Herold MJ, van Delft MF, Bedoui S, Lessene G, Ritchie ME, Huang DC, Kile BT. Apoptotic caspases suppress mtDNAinduced STING-mediated type I IFN production. Cell. 2014; 159:1549-62. https://doi.org/10.1016/j.cell.2014.11.036. [PubMed]

32. Perciavalle RM, Stewart DP, Koss B, Lynch J, Milasta S, Bathina M, Temirov J, Cleland MM, Pelletier S, Schuetz JD, Youle RJ, Green DR, Opferman JT. Anti-apoptotic MCL-1 localizes to the mitochondrial matrix and couples 
mitochondrial fusion to respiration. Nat Cell Biol. 2012; 14:575-83. https://doi.org/10.1038/ncb2488. [PubMed]

33. Eichhorn JM, Alford SE, Sakurikar N, Chambers TC. Molecular analysis of functional redundancy among antiapoptotic Bcl-2 proteins and its role in cancer cell survival. Exp Cell Res. 2014; 322:415-24. https://doi.org/10.1016/j. yexcr.2014.02.010. [PubMed]

34. El-Brolosy MA, Stainier DYR. Genetic compensation: A phenomenon in search of mechanisms. PLoS Genet. 2017; 13:e1006780. https://doi.org/10.1371/journal.pgen.1006780. [PubMed]

35. Duprez L, Wirawan E, Vanden Berghe T, Vandenabeele P. Major cell death pathways at a glance. Microbes Infect. 2009; 11:1050-62. https://doi.org/10.1016/j. micinf.2009.08.013. [PubMed]

36. Martinou JC, Youle RJ. Mitochondria in apoptosis: Bcl-2 family members and mitochondrial dynamics. Dev Cell. 2011; 21:92-101. https://doi.org/10.1016/j. devcel.2011.06.017. [PubMed]

37. Chonghaile TN, Roderick JE, Glenfield C, Ryan J, Sallan SE, Silverman LB, Loh ML, Hunger SP, Wood B, DeAngelo DJ, Stone R, Harris M, Gutierrez A, et al. Maturation stage of T-cell acute lymphoblastic leukemia determines BCL-2 versus BCL-XL dependence and sensitivity to ABT-199. Cancer Discov. 2014; 4:1074-87. https://doi. org/10.1158/2159-8290.CD-14-0353. [PubMed]

38. Anderson NM, Harrold I, Mansour MR, Sanda T, McKeown M, Nagykary N, Bradner JE, Lan Zhang G, Look AT, Feng H. BCL2-specific inhibitor ABT-199 synergizes strongly with cytarabine against the early immature LOUCY cell line but not more-differentiated T-ALL cell lines. Leukemia. 2014; 28:1145-8. https://doi.org/10.1038/leu.2013.377. [PubMed]

39. Frismantas V, Dobay MP, Rinaldi A, Tchinda J, Dunn SH, Kunz J, Richter-Pechanska P, Marovca B, Pail O, Jenni S, Diaz-Flores E, Chang BH, Brown TJ, et al. Ex vivo drug response profiling detects recurrent sensitivity patterns in drug-resistant acute lymphoblastic leukemia. Blood. 2017; 129:e26-e37. https://doi.org/10.1182/blood-2016-09-738070. [PubMed]

40. Khaw SL, Suryani S, Evans K, Richmond J, Robbins A, Kurmasheva RT, Billups CA, Erickson SW, Guo Y, Houghton PJ, Smith MA, Carol H, Roberts AW, et al. Venetoclax responses of pediatric ALL xenografts reveal sensitivity of MLL-rearranged leukemia. Blood. 2016; 128:1382-95. https://doi.org/10.1182/blood-2016-03-707414. [PubMed]

41. Peirs S, Matthijssens F, Goossens S, Van de Walle I, Ruggero K, de Bock CE, Degryse S, Cante-Barrett K, Briot D, Clappier E, Lammens T, De Moerloose B, Benoit Y, et al. ABT-199 mediated inhibition of BCL-2 as a novel therapeutic strategy in T-cell acute lymphoblastic leukemia. Blood. 2014; 124:3738-47. https://doi.org/10.1182/ blood-2014-05-574566. [PubMed]

42. Lin KH, Winter PS, Xie A, Roth C, Martz CA, Stein EM, Anderson GR, Tingley JP, Wood KC. Targeting MCL-1/
BCL-XL Forestalls the Acquisition of Resistance to ABT199 in Acute Myeloid Leukemia. Sci Rep. 2016; 6:27696. https://doi.org/10.1038/srep27696. [PubMed]

43. Luedtke DA, Niu X, Pan Y, Zhao J, Liu S, Edwards H, Chen K, Lin H, Taub JW, Ge Y. Inhibition of Mcl-1 enhances cell death induced by the Bcl-2-selective inhibitor ABT-199 in acute myeloid leukemia cells. Signal Transduct Target Ther. 2017; 2:17012. https://doi.org/10.1038/sigtrans.2017.12. [PubMed]

44. Yecies D, Carlson NE, Deng J, Letai A. Acquired resistance to ABT-737 in lymphoma cells that up-regulate MCL-1 and BFL-1. Blood. 2010; 115:3304-13. https://doi.org/10.1182/ blood-2009-07-233304. [PubMed]

45. Rooswinkel RW, van de Kooij B, Verheij M, Borst J. $\mathrm{Bcl}-2$ is a better ABT-737 target than Bcl-xL or Bcl-w and only Noxa overcomes resistance mediated by Mcl-1, Bfl-1, or Bcl-B. Cell Death Dis. 2012; 3:e366. https://doi. org/10.1038/cddis.2012.109. [PubMed]

46. Leverson JD, Phillips DC, Mitten MJ, Boghaert ER, Diaz D, Tahir SK, Belmont LD, Nimmer P, Xiao Y, Ma XM, Lowes KN, Kovar P, Chen J, et al. Exploiting selective BCL-2 family inhibitors to dissect cell survival dependencies and define improved strategies for cancer therapy. Sci Transl Med. 2015; 7:279ra40. https://doi.org/10.1126/scitranslmed. aaa4642. [PubMed]

47. Inoue-Yamauchi A, Jeng PS, Kim K, Chen HC, Han S, Ganesan YT, Ishizawa K, Jebiwott S, Dong Y, Pietanza MC, Hellmann MD, Kris MG, Hsieh JJ, et al. Targeting the differential addiction to anti-apoptotic BCL-2 family for cancer therapy. Nat Commun. 2017; 8:16078. https://doi. org/10.1038/ncomms16078. [PubMed]

48. Ashkenazi A, Fairbrother WJ, Leverson JD, Souers AJ. From basic apoptosis discoveries to advanced selective BCL-2 family inhibitors. Nat Rev Drug Discov. 2017; 16:273-84. https://doi.org/10.1038/nrd.2016.253. [ubMed]

49. Opferman JT. Attacking cancer's Achilles heel: antagonism of anti-apoptotic BCL-2 family members. FEBS J. 2016; 283:2661-75. https://doi.org/10.1111/febs.13472. [PubMed]

50. Kotschy A, Szlavik Z, Murray J, Davidson J, Maragno AL, Le Toumelin-Braizat G, Chanrion M, Kelly GL, Gong JN, Moujalled DM, Bruno A, Csekei M, Paczal A, et al. The MCL1 inhibitor S63845 is tolerable and effective in diverse cancer models. Nature. 2016; 538:477-82. https:// doi.org/10.1038/nature19830. [PubMed]

51. Konopleva M, Contractor R, Tsao T, Samudio I, Ruvolo PP, Kitada S, Deng X, Zhai D, Shi YX, Sneed T, Verhaegen M, Soengas M, Ruvolo VR, et al. Mechanisms of apoptosis sensitivity and resistance to the BH3 mimetic ABT-737 in acute myeloid leukemia. Cancer Cell. 2006; 10:375-88. https://doi.org/10.1016/j.ccr.2006.10.006. [ PubMed]

52. Walensky LD, Pitter K, Morash J, Oh KJ, Barbuto S, Fisher J, Smith E, Verdine GL, Korsmeyer SJ. A stapled BID BH3 helix directly binds and activates BAX. Molecular Cell. 2006; 24:199-210. https://doi.org/10.1016/j. molcel.2006.08.020. [PubMed] 
53. Horn H, Ziepert M, Becher C, Barth TF, Bernd HW, Feller AC, Klapper W, Hummel M, Stein H, Hansmann ML, Schmelter C, Moller P, Cogliatti S, et al. MYC status in concert with BCL2 and BCL6 expression predicts outcome in diffuse large B-cell lymphoma. Blood. 2013; 121:2253-63. https://doi.org/10.1182/blood-2012-06-435842. [PubMed]
54. Lenz G, Staudt LM. Aggressive lymphomas. N Engl J Med. 2010; 362:1417-29. https://doi.org/10.1056/ NEJMra0807082. [PubMed] 